\title{
10 minutes with Dr Claire Dewsnap, consultant in genitourinary medicine at Sheffield Teaching Hospitals
}

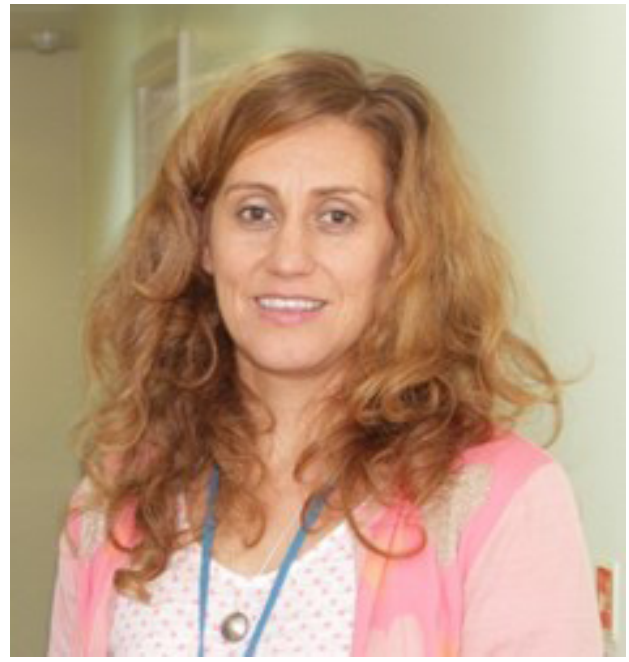

\section{WHAT ARE THE KEY LEADERSHIP MESSAGES YOU WANT TO GET OUT TO THE BMJ LEADER READERSHIP?}

The key messages I would like to get out to all leaders at any level is to be available and accessible. When I say available, I mean available to listen to all staff members regardless of their status or stature. It is important to understand the team as a whole and to make sure you are continually listening and responding to feedback. In relation to COVID-19, this is particularly important as we are all having to learn and adapt quickly. Along a similar vein, try to be open to doing a wide range of tasks even if they seem menial. If people see you adapting and doing different things, even if they are at the edge of your comfort zone, it will help them to feel empowered to do so also.

\section{TELL US A LITTLE BIT ABOUT YOUR LEADERSHIP ROLE AND HOW IT IS CHANGING AS A RESULT OF THE PANDEMIC}

In some ways, my day-to-day role is changing a lot, so I am no longer dealing withgenito-urinary medicine problems but I am now managing acute respiratory problems. However, the leadership role is very similar. As a consultant and as you start to take on more leadership roles, you start to appreciate that it's not just about clinical knowledge, it's about how you can manage a team. It is just as important to be able to get the best from the whole team as it is to understand clinically what is going on. Luckily, that knowledge is transferable. Knowing how and when to delegate and confidence in your leadership skills are skills that are transferable to all wards and environments.

\section{WHAT EVENTS IN YOUR PAST EXPERIENCE ARE MOST INFORMING YOUR LEADERSHIP IN THIS PANDEMIC?}

I became clinical lead when I was only 2 years into my consultant role; this meant I had to lead significantly more senior consultants than myself. This was a problem our new ward could have faced, as I am not an expert respiratory physician or infectious disease consultant, but I would be working alongside these colleagues. The skills I developed from being a relatively junior clinical lead and managing hierarchical problems therefore came in use here. Throughout medicine being able to manage both up and down is really important. Also, the more you progress in your career,
Biography

Claire Dewsnap is a consultant in genitourinary medicine at Sheffield Teaching Hospitals. She qualified in 1997 from Sheffield University and undertook her general medical training in Liverpool, beginning her consultant role in Rotherham in 2006. She very quickly stepped up to the role of clinical lead in 2009. She held the post for 3 years before taking up the post of clinical lead at Sexual Health Sheffield. Her main passion has been helping to support junior doctors. After stepping down from the role of clinical lead in 2016 she took on the role of training programme director for the foundation year 1 doctors. Alongside this, she plays an active role in the development of the NHS, having held the post of clinical lead for quality improvement. During the COVID-19 pandemic, she has been asked to step away from her genito-urinary medicine post to manage a newly created COVID-19 ward. Alongside this, she continues to fulfil her role as training programme director for the new foundation year 1 doctors starting their rotations earlier than expected.

the more you realise as a doctor you are always working on the edge of your clinical comfort zone anyway. The more senior you become, the more complex the decisions become, so you get increasingly more comfortable with it.

\section{WHAT ARE YOU FINDING THE BIGGEST CHALLENGES?}

Working in a new role can be a challenge, especially in this setting, as the clinical skills I would require were not my dayto-day ones. But to be honest, I think I've been lucky as the team here has genuinely been amazing: both friendly, skilled and hardworking, all of which has made my job a lot easier. As I identified before, a potential challenge I could have faced was working alongside people who were more knowledgeable than myself but that I would be classed as more senior too. That always has the potential to cause tensions, but again just being relaxed and feeling comfortable about this is important. I see it more as my role to bring out those different kinds of expertise rather than be put down by them. The other challenge we were all faced with on this ward was integrating staff from all different departments that all had different skill sets. I found in this situation it was really important to break down hierarchical walls. We needed to all be able to freely ask each other questions without feeling we were being stupid. The way we all successfully dealt with this really was just by being open and approachable; we had morning multi-disciplinary team meetings which were inclusive of everyone, and we all called each other by our first names. The little things really mattered.

\section{ANY PARTICULAR SURPRISES?}

Well I've been surprised by how much I missed acute ward work! But from a leadership point of view, I know the NHS responds well in a crisis, so the impressive response to COVID-19 with the level of structural change we've managed to achieve in such a short length of time has not surprised me. It has, however, made me think how we need to improve our response to the day-to-day challenges we face. Often we find on a day-to-day it is hard to create change in the NHS, but this has demonstrated 
how we can do this. We've managed to change rotas, consultant availability, clinical structures all in a matter of weeks. We need to build on these skills so we can more readily adapt on an individual or daily basis.

\section{ARE YOU SEEING ANY BEHAVIOURS FROM COLLEAGUES THAT ENCOURAGE OR INSPIRE YOU?}

Yes, definitely! The ward sister who was appointed to manage this new COVID-19 ward has been amazing. She really managed to bring two teams together, mainly just by promoting excellent communication between everyone, which has meant there hasn't been any tension between staff from different areas. She's transparent and fair and doesn't prefer her nurses over nurses from other departments. Like I said before, the little things are important, so she remembers staff names and is always offering to help, even if it's something silly like locating a cheese sandwich! Other little examples of leadership I've seen have been from lots of staff across the department. Things like clearly explaining thought processes behind decisions or listening to what's important to other members of the team.

\section{HOW ARE YOU MAINTAINING KINDNESS AND COMPASSION?}

So I always try to be approachable; I communicate clearly with people both kindly and thoughtfully. I try to make people feel valued by understanding who they are as a person, not just their role. I always model a team approach by helping with tasks across all roles and encouraging others to do so as well. Lastly, I'm accessible; staff have my number, I try to stay visible on the ward, and if I'm not there, then I let staff know where I'll be.

\section{ARE THERE ANY IDEAS OR READINGS THAT YOU FIND HELPFUL, FOR INSPIRATION AND SUPPORT, WHICH YOU WOULD RECOMMEND TO OTHERS?}

I like the Faculty of Medical Leadership and Management ${ }^{1}$; they have really useful resources. Local quality improvement programmes can also be very useful. When I'm doing my appraisal, I think about the general areas of leadership and try to develop these areas as appropriate. For example, undertaking psychometric tools in the context of leadership and development or attending quality improvement courses can be used to improve performance.

\section{WHAT ARE YOU LOOKING FOR FROM YOUR LEADERS?}

I'm looking for more accessibility. I'd like them to be more transparent and visible to the team. Specifically, there needs to be more active listening, so they need to seek out opinion on the shop floor from a variety of different roles.

\section{Grace Webster, ${ }^{1}$ Claire Dewsnap ${ }^{2}$}

${ }_{1}^{1}$ Infectious Diseases, Sheffield Teaching Hospitals NHS Foundation Trust, Sheffield, UK ${ }^{2}$ Genito-urinary Medicine, Sexual Health Sheffield, Sheffield, UK

\section{Correspondence to}

Dr Grace Webster, Infectious Diseases, Sheffield Teaching Hospitals NHS Foundation Trust, Sheffield S10 2JF, UK; gracewebster@hotmail.co.uk

Contributors $C D$ is the doctor I interviewed.

Funding The authors have not declared a specific grant for this research from any funding agency in the public, commercial or not-for-profit sectors.

Competing interests None declared.

Patient consent for publication Not required.

Provenance and peer review Not commissioned; externally peer reviewed.

Data availability statement No data are available.

This article is made freely available for use in accordance with BMJ's website terms and conditions for the duration of the covid-19 pandemic or until otherwise determined by BMJ. You may use, download and print the article for any lawful, non-commercial purpose (including text and data mining) provided that all copyright notices and trade marks are retained.

(C) Author(s) (or their employer(s)) 2020. No commercial re-use. See rights and permissions. Published by BMJ.

\section{Check for updates}

To cite: Webster G, Dewsnap C. BMJ Leader 2020;4:260-261.

Received 22 May 2020

Revised 17 June 2020

Accepted 24 June 2020

Published Online First 10 July 2020

BMJ Leader 2020:4:260-261.

doi:10.1136/leader-2020-000297

\section{REFERENCE}

1 Faculty of Medical Leadership and Management. Covid-19 leadership. Available: https://www.fmlm.ac.uk/covid-19/leadership [Accessed 17th Jun 2020]. 